\title{
Communist Geography Instead of Nationalist Geography: The New Cadres and the Case of Sándor Radó ${ }^{1}$
}

\section{Róbert Győri}

\begin{abstract}
This article provides an introduction to the scholarly career of Sándor Radó (1899-1981), one of the leading Hungarian geographers and cartographers of the 1960s and 1970s. Belonging to a generation of newcomers who took control of every aspect of Hungarian scholarly life in the 1950s after the ousting of the old elite, Radó's scholarly path was not unique. The complete transformation of Hungarian geography was deeply embedded within this broader process, as its nature, approaches, conduct, and institutional organization was rearranged along Marxist-Leninist ideological lines. A critical examination of Radó's career and his scientific work, therefore, helps us to understand how Hungarian science functioned during the 1950s, 1960s, and 1970s, and provides insight into the practice of career and institution building, and thus reveals the atmosphere within which scientific results were achieved.
\end{abstract}

Keywords: Sándor Radó, Stalinization of Hungarian Geography, Communist Cadres, Scientific Life in Communist Hungary

Biography: Róbert Győri is associate professor and Chair of the Department of Social and Economic Geography at Eötvös Loránd University, Budapest (ELTE). He is also head of the Tibor Mendöl Geography and Earth Sciences Workshop at the Eötvös József Collegium of ELTE. He received his Ph.D. in geography from ELTE in 2006 and habilitated at the same university in 2014. His research fields include historical geography, urban geography, and the history of geographical knowledge. His current research focuses on how science is controlled and managed by totalitarian regimes, and how Hungarian geography in particular was crushed as a result of Soviet-era transformations.

\footnotetext{
${ }^{1}$ This paper was supported by the János Bolyai Research Scholarship of the Hungarian Academy of Sciences.
} 
Győri, Róbert. "Communist Geography Instead of Nationalist Geography: The New Cadres and the Case of Sándor Radó." Hungarian Cultural Studies. e-Journal of the American Hungarian Educators Association, Volume 8 (2015): http://ahea.pitt.edu DOI: 10.5195/ahea.2015.222

\section{Introduction}

The process of sovietization that consumed Hungary at the end of the 1940s and throughout the 1950s has long been a taboo subject amongst historians of Hungarian geography. Though Zoltán Hajdú published a number of archivally-based studies on this topic immediately after the change of regime in 1989-1990 (see for example Hajdú 1990-91, Hajdú 1992), the issue did not become the focus of wide-ranging debate, nor did it catch the attention of those geographers who perhaps should have been dedicating themselves to this question over the years. This strange silence is not just confined to the 1950s, as neither the 1990s nor the 2000s produced comprehensive studies on the nature of socialist geography. Geography was by no means alone in this silence, or in the suppression of discussion on this topic. For the most part, Hungarian social sciences has not faced up to socialism's past, while a work like Ignác Romsics's recently published study on the sovietization of the discipline of history generated much discussion and heated debate (Romsics 2011). Though the sharp criticism was not directed against Romsics's main thesis, the bitter nature of the debate indicates that a hornet's nest awaits any researcher who addresses this theme.

The blind spots that persist within the history of science in Hungary are products of interconnected factors whose formation, in my opinion, can largely be explained in terms of the postsocialist condition. A number of closely connected meanings are woven into the concept of postsocialism. A definition of postsocialism, therefore, may include any (or all) of the following: "1) an epoch with historical and structural explanations of demarcation; 2) a state of society or mind (for example culture or psychology) which might still linger on in inherited structures; or 3) a critical epistemology for approaching the middle ground between 'capitalist' and 'socialist' worlds" (Gyimesi 2014). For this current study, the second meaning is the most important, as the structures developed during the decades of socialism have survived in every segment of Hungarian society, and are conspicuous within scholarly life as well. For the most part, the regime change does not represent a clear fault line within Hungarian social sciences. In contrast to what took place at the end of the 1940s and the beginning of the 1950s in the context of Stalinization, there was no purging of individuals twenty-five years ago, nor was there an attempted rebuilding of the institutional order, or a compulsory ideological shift. In some academic disciplines (including, to some extent, human geography), the scholarly elite of the 1970s and 1980s managed to preserve their positions with relatively little difficulty despite the changed circumstances. Emphasizing the value-neutral, objective character of their earlier research results, these academics attempted to secure their elite positions and scholarly prestige, and stressed that pragmatically-oriented, technocratic knowledge is useful to every kind of regime, and that their work would also be needed as Hungary transitioned back to capitalism, and set its sights on integration into the European Union.

Research into the history of science under socialism (and in particular that of the 1970s and 1980s) proved particularly awkward for the scholarly elite of the late Kádár period, as such research would not only have exposed the false neutrality of socialist science, but also would have shattered the myth of objectivity that scholars often stressed, and thus would have undermined the academic legitimacy of an entire generation. Indeed, no scientific knowledge is 
Győri, Róbert. "Communist Geography Instead of Nationalist Geography: The New Cadres and the Case of Sándor Radó." Hungarian Cultural Studies. e-Journal of the American Hungarian Educators Association, Volume 8 (2015): http://ahea.pitt.edu DOI: 10.5195/ahea.2015.222

"value-neutral," and it is for this reason that, in this study, I draw on the works of scholars who, in their critical examination of the history of geography, argue that the history of science can not be understood outside of the broader social, political, and economic context within which the scholarship and knowledge of a particular period is embedded (Livingstone 1992). Scientific production, in short, is in no way independent from the time or place it is produced. In the end, the history of geographical science under socialism is inseparable from the history of socialist Hungary.

In this article, I would like to explore a scholarly career whose every element was a product of socialism. Sándor Radó (1899-1981) had played an active role in the international labor movement and, as a law student, had been a political officer of the Hungarian Red Army during the Hungarian Soviet Republic of 1919. After the downfall of that republic, he emigrated to Vienna, and then to Germany. He studied geography and history at the universities of Jena and Leipzig, but according to the research of Ferenc Gyuris, official university documents prove that he did not complete his studies. After spending a semester in Jena in 1922-1923, Radó moved to Leipzig, where he began studies in the same disciplines, but he was expelled in 1925 on account of "not attending lectures" (Györi and Gyuris 2015). Finally, Radó went to the Soviet Union, where he gained a reputation as a cartographer, and, according to a CIA report, was trained there for service with Soviet military intelligence (Thomas 1968). Following some years in the USSR, he moved to Germany, then to Paris. From 1936, he lived in Geneva until 1944, where he was a secret agent of Soviet intelligence under the umbrella of the news agency Geopress (as I discuss below, Radó wrote an autobiographical fiction (Radó 1971) about his Soviet intelligence service, which was brought to the big screen during his lifetime). In 1945, he was evacuated from Paris to the Soviet Union, where he was accused of working for the British as a double agent and was sentenced to ten years of forced labor in 1946 (Trom 2006). He was not released until November of 1954, although according to U.S. intelligence he spent only a short time in a Siberian coalmine, where he managed teams of workers and thus was not subject to hard physical labor. Thereafter, he was transferred to a geographical observatory near Moscow as a "prisoner with privileges" (the CIA assumed that Radó's transfer and special treatment were the result of "string-pulling by friends") (Thomas 1968).

Though Radó managed to produce numerous studies, even during the most adventurous decades of his life (see for example Heffernan 2015), there have been few attempts to provide a comprehensive assessment of his life's work (Heffernan and Györi 2014), especially as this pertains to his socialist-era scholarship. My study, therefore, addresses this lacuna, and in so doing attempts to further develop the critical examinations that exist with respect to the scholarly output of Hungary's geographical and earth science cadres under socialism.

\section{"Old" and "New" Geography: A Brief Career History}

Sándor Radó was release from forced labor after Stalin's death on November 25, 1954, and after thirty-five years of absence returned to Hungary in July 1955 (Poltorak 2010, Trom 2010). In 1919, the then 20 -year-old Radó had left a short-lived, fallen Hungarian Soviet Republic (Magyar Tanácsköztársaság), and now returned to the communist People's Republic of 
Győri, Róbert. "Communist Geography Instead of Nationalist Geography: The New Cadres and the Case of Sándor Radó." Hungarian Cultural Studies. e-Journal of the American Hungarian Educators Association, Volume 8 (2015): http://ahea.pitt.edu DOI: 10.5195/ahea.2015.222

Hungary (Magyar Népköztársaság). In the time that had lapsed between these two events, both the country's political structure and the nature of Hungarian geography had changed substantially.

The collapse of the defeated Austro-Hungarian Empire in the wake of World War I had a profound impact on the Hungarian Kingdom: two-thirds of its territory and 60\% of its population was annexed to the new states that emerged out of the ruins of the Empire. The shock associated with the decision to dismember the prewar Kingdom of Hungary determined Hungarian public opinion for decades, and with this also shaped Hungarian scholarship and knowledge production. Most of the humanities and the social sciences - among all of them especially geography - were mobilized between the two World Wars to actively support and legitimize the most important goals of the interwar conservative-nationalist regime, and in particular the revision of the devastating peace treaty imposed on Hungary at the end of World War I. The Hungarian government's attempts at territorial revisionism only achieved success on the eve of World War II. The price of this success, however, was that Hungary was compelled to enter into the war on the Axis side. At the end of the war, Hungary fell into the Soviet occupation zone, and with this began the Stalinist transformation of the country.

The establishment of a communist regime in Hungary and the implementation of a new cultural policy transformed Hungarian scientific life as the academic institutional system was adjusted to the Soviet model, and Marxism-Leninism became the foundational worldview of every discipline. This conversion had an especially severe affect on Hungarian geography, which had been deemed by the communists as a science that had previously served the reactionary, conservative-nationalist system. As early as 1949, in fact, geographical fellows of the Hungarian Academy of Sciences (Magyar Tudományos Akadémia, HAS) were expelled, and in the same year the operations of the Hungarian Geographical Society (Magyar Földrajzi Társaság) were also suspended (Koch 1952, Gyuris and Győri 2013). Former leading geographers were either pushed into retirement or were forced to leave their field, while those who managed to hold onto their positions found themselves in the crossfire of scholarly attacks. Others chose to compromise with the new system, though this compromise was rarely sincere. The now vacant and newly created positions were filled by party-loyal cadres who, without either geographical education or a university degree, were returning home after the war from exile either in the Soviet Union or in the West. By the middle of the 1950s, the uneven battle between the "old" and the "new" geography had largely abated, though rearguard actions were still being fought by some, and ideological debates and libelous personal attacks lingered on (Győri and Gyuris 2012).

Radó arrived into this environment, and his rapidly accelerating career shows that the political and scientific leadership in communist Hungary looked favorably upon him as a wellproven cadre. It might seem curious that his reputation was not damaged by the fact that he had been imprisoned in the Soviet Union, but the jailing of the system's admirers in the Stalinist period was not at all exceptional (in fact, in this era in Hungary, many communist politicians suffered imprisonment due to conflicts within the party; some of them were sentenced to death and executed on trumped-up charges, but most of them were rehabilitated after a few years). It is likely that Radó's speedy integration was largely facilitated by his expansive network of 
friendships with the veterans of the Hungarian Soviet Republic. His return home from the Soviet Union, for example, was supported by his onetime fellow combatant, Ferenc Münnich (then ambassador to Moscow, later Minister of the Interior), while in Hungary his old schoolmate, Ernő Gerö, was helpful (Thomas 1968). ${ }^{2}$ (Gerö's political career also began with the Hungarian Soviet Republic; he eventually rose to become second in line to the leadership of the communist party in the 1950s, and after Mátyás Rákosi's dismissal in 1956 he became its leader.) The returning Radó was offered a position as Deputy Minister of the Interior and as supervisor of the Hungarian intelligence agency, but he rejected these offers, replying that he wanted to keep himself away from politics, and would rather deal with science (Trom 2006).

Having declared his desire to engage in academic work, Radó entered into the vascular network of Hungarian geography, into a milieu he did not know, and into a world in which he was not known. His cartographic works published outside Hungary between the two world wars (for example Radó 1938) were not known in Hungarian geographical circles at the time, and, in the first decades after the Second World War, Radó was left out of the Marxist-Leninist geographical canon because of his Soviet imprisonment. Moreover, his intelligence activity was also concealed from the Hungarian public, for obvious reasons. However, despite having neither a university degree nor any professional contacts, Radó eventually rose to the top of the academic hierarchy, due exclusively to the strong political support he received.

After his return from the Soviet Union, Radó worked for a brief period at the Ministry for Foreign Trade (Külkereskedelmi Minisztérium), then on September 15, 1955 he became the divisional head of the cartography group organized for him at the State Office of Land Survey and Cartography (Állami Földmérési és Térképészeti Hivatal, ÁFTH) (he held this position until his retirement in 1978). Apart from this, from January 1, 1956 to April 30, 1956 he was also head engineer of the national map and atlas publishing company, Kartográfiai Vállalat ['Cartographical Company'], serving as the head of the company's editorial board between 1956 and 1978 (Hegyi 1998) (in practice, these functions meant that Sándor Radó controlled Hungarian civil cartography for decades). Radó's star rose quickly. Not even a year had passed since his return to Hungary when the Hungarian Geographical Society, reestablished only a few years before, honored him. At their general meeting held on April 20, 1956 he was elected as honorary fellow of the Society, while in 1959 he was appointed as its vice president (Somogyi 1998). Apart from his other duties and occupations, Radó even applied for a university chair. His original ambition was to become professor and department head at Eötvös Loránd University (ELTE) in Budapest, but instead the Karl Marx University of Economics (Marx Károly

\footnotetext{
${ }^{2}$ It is not easy of course to claim something on the background of his homecoming, since, for example, Radó's later colleague, Gyula Bora remembered Radó telling him that Gerő was then against his return. (Bora 1998)
} 
Győri, Róbert. "Communist Geography Instead of Nationalist Geography: The New Cadres and the Case of Sándor Radó." Hungarian Cultural Studies. e-Journal of the American Hungarian Educators Association, Volume 8 (2015): http://ahea.pitt.edu DOI: 10.5195/ahea.2015.222

Közgazdaságtudományi Egyetem, MKKE) offered him a position. As one of his colleagues expressed, Radó "agreed, at last, to let politics call him to us [végül beleegyezett, hogy a politika hozzánk szólitsa] (Bora 1998: 110). The position itself had opened up because the Ministry of Education (Oktatási Minisztérium) fired György Markos in 1958. Though he had been the most combative Marxist-Leninist geographer of the transformation to communism in the 1950s, he was removed from his position at $M K K E$ because of his affiliation with an intellectual organization connected to the 1956 revolution. His department, the Department of Economic Geography (Gazdaságföldrajzi Tanszék) was taken over by Radó on September 1, 1958 (Bora 1998).

At the time of his departmental and professorial assignment, Radó still possessed neither a diploma, nor an academic degree (he was not alone in this amongst the newly-appointed university professors of the 1950s). This "oversight" was corrected by the Hungarian Academy of Sciences (HAS) on September 22, 1958 by granting Radó (along with many other researchers) the highest attainable degree, the "Doctor of Sciences" (DSc), which was formerly introduced following the Soviet model (Kubassek 2010). This peculiar "granting" of a degree without a dissertation and its defense was as shocking then as it would be today. Then, as now, the Academy seldom granted this degree, which in most Hungarian universities is the prerequisite for full-professorship. The Academy was especially limiting with geographers: those professors who earned their titles before the 1950s had to be reaccredited by the new system, first by attaining the same Soviet modelled candidate degree (CSc, which was a prerequisite to become a reader [docens] in universities), then the "Doctor of Sciences" (DSc) title. Achieving these titles (without political support) was simply impossible even for department heads with considerable lifetime achievements. Ferenc Fodor for example, who became a habilitated professor in the early 1920s at the Faculty of Economics (Közgazdaságtudományi Kar) - precisely at the same department where Radó later became head - applied for the candidate title five times, but the Academy ignored the already-retired professor's request (Jobbitt 2014). Tibor Mendöl, who was head of department at the university in Budapest (but excluded from an Academy fellowship), also saw his DSc-dissertation "considered" for years. Though Mendöl was eventually successful, it was not until after his death that was posthumously awarded the "Doctor of Sciences" title (Györi 2009). To my knowledge, Radó was the only Hungarian geographer who received the DSc degree without handing in a dissertation.

The rapid development of Radó's scientific career not surprisingly met with disapprobation within the professional community, and in almost all of his workplaces he came into conflict with colleagues of the "old" regime. The academic István Klinghammer, for example, wrote the following: "after his return, [Radó] blasted into local professional-academic life in a 'Stalinist style'. He insulted many and treated people unworthily, and hence gained many enemies" [hazatérése után "sztálinista stílussal" robbant be a hazai szakmai-tudományos életbe. Sok embert megbántott, hozott méltatlan helyzetbe, és bizony sok haragost szerzett] (Klinghammer 2010: 10). Quarrels often sprung from professional matters, and from these conflicts Radó came out victorious almost every time. At Kartográfiai Vállalat Radó sparked debate on the production and priority order of various atlases and on other financial questions, 
Győri, Róbert. "Communist Geography Instead of Nationalist Geography: The New Cadres and the Case of Sándor Radó." Hungarian Cultural Studies. e-Journal of the American Hungarian Educators Association, Volume 8 (2015): http://ahea.pitt.edu DOI: 10.5195/ahea.2015.222

and it was only years later (after the retirement or removal of previous colleagues) that the conflict was settled (Hegyi 1998). In another case, the forced retirement of the leading cartographer, József Takács - a move that was seen by some as a form of punishment—was the direct result of the objection raised by Radó that this "old" colleague had put too much emphasis on Hungarian cartography's pre-1945 achievements in one of his articles on the history of science, and too little emphasis on the merits of state cartography initiated after 1954 (Földi 1998). Radó was also the source of conflict with "bourgeois" geography professors who were criticized for receiving "unduly high" royalties for their editing of the so-called university atlas. As a result of this controversy, the Ministry of Education stopped the production of the atlas (Papp-Váry 1998b). Radó was merciless in his attacks against even the highest scholarly circles: after his return home, for instance, he labelled many HAS fellows as reactionary, and in at least one case even fascist (Kubassek 2010, Kisari Balla 1999), and this despite the fact that the membership of the Academy had already been significantly transformed as a result of the political cleansings of 1949 (Péteri 1998). György Kisari Balla, a cartographer of ÁFTH, summarized the working atmosphere of the second half of the 1950s thusly: "We dreaded him. A good word from him meant a raise, a bad opinion a career change" [Reszkettünk töle. Egy jó szava fizetésemelést, rossz véleménye pályamódositást jelentett] (Kisari Balla 1999: 1). Given all of this, it is no small wonder that the workers' council formed at ÁFTH during the 1956 revolution demanded, in a resolution, the removal of Radó (among many other communist leaders) (ÁBTL O-16896).

Besides his academic work, it is still an open question whether or not Radó engaged in any intelligence activity after his return to Hungary. Radó himself told his stepson that, in 1955, both the Soviet and the Hungarian authorities offered him their cooperation, but that he rejected these offers (Trom 2010). However, the CIA's material on Radó strongly suggests that this was a possibility. Having knowledge of Radó's successful history of espionage between the two world wars, the Americans feared that Radó might use his leadership role in Hungarian geography and cartography for collecting information (Thomas 1968). Radó participated in international conferences and made professional trips abroad several times a year (something that was rare amongst his Hungarian contemporaries), and also held positions in a number of international professional organizations. In addition, because of his wide-ranging organizational and editorial work in cartography, he corresponded with scores of foreign partners, and made many requests for fresh maps and statistical data to feed his various publications (Zentai 2010). The suspicion of the CIA was above all that Radó was transmitting these maps and information to the Soviets, so they warned Radó's American partners not to support him with any materials (Thomas 1968). This suspicion is not confirmed by the archives of the State Security Service (Állambiztonsági Szolgálat). I myself have been faced with the fact that the Radó file at the State Security Service is rather thin (ÁBTL A-748), and this limited material primarily focusses on Radó's Swiss activity during and after WWII. This is rather strange because it very likely that Radó received at least some state security protection. It is also peculiar that no reports on his foreign travels exist (although handing these in was obligatory) (Izsa 2010). It could be that the elucidation of Radó's possible activity in Hungarian intelligence will be discovered as more archival material is 
Győri, Róbert. "Communist Geography Instead of Nationalist Geography: The New Cadres and the Case of Sándor Radó." Hungarian Cultural Studies. e-Journal of the American Hungarian Educators Association, Volume 8 (2015): http://ahea.pitt.edu DOI: 10.5195/ahea.2015.222

processed, but it could also be assumed that he never performed such tasks for Hungary. If he had worked for the Soviet Union in the 1960s and 1970s, then scarce traces of this were left in the Hungarian archives. Moreover, research in the Russian archives is impeded because most of the documents on Radó are still classified (Poltorak 2010).

The Hungarian public and the professional community learned of Radó's secret agent past in a very extraordinary way. The Hungarian delegation arriving at the International Geographical Union (IGU) conference in Stockholm in 1960 were shocked by the large posters of Swedish news that they saw, which had declared in the headlines that a superspy had arrived at the conference in Stockholm. Radó was swarmed by reporters, and the "unmasking" of Radó became one of the greatest sensations of the conference (Bora 1998). After this revelation, Hungarian (and Soviet) propaganda attempted to capitalize upon the situation to mythologize Radó as the anti-fascist hero of WWII. The idea first emerged in 1967 in the Soviet Union to have a journalist write up the story of Radó's Swiss espionage as a youth novel (Trom 2010). The planned volume would have presented events from Radó's perspective, and as a matter of course it would have followed the political needs of the Soviet Union of the 1960s. The novel's message would have been to confront existing opinions that suggested that the defeat of Germany was due to excellent Western intelligence and not to Soviet military and strategic effort. In the end Radó did not allow someone else to write the story, and instead wrote his memoir Dóra jelenti ['Codename Dóra'], which was first published in Hungarian in 1971. (The original manuscript was censored by both Soviet and Hungarian authorities, deleting about 10\% of its content; see Trom 2006). The book (obviously thanks to background support again) was a big success in Hungary and other countries as well: it ran to four editions in Hungarian (Radó 1971, 1972, 1977, 1978, 2006) and was translated into 23 languages (in all Western world languages (English edition: Radó 1977) and in the languages of socialist countries). In Hungary the book became an "anti-fascist oratory", and —in Radó's lifetime — even a film was made (in 1978), which was a box-office failure despite the fact that the main roles were played by leading stars of the age. The book presented Radó's career as living up to the socialist expectations of the ideal man: the hero "obeys" the challenges given to him by the grand idea, and in essence sacrifices himself for the greater good (Nagy E. Á. 2010). Naturally, both the book and the film passed over Radó's post-1945 experiences in the Soviet Union in silence.

Radó's scientific and public career reached its height in the second half of the 1960s and continued into the 1970s. Owing to his powerful scientific and political positions, he was able, on the one hand, to strengthen the position of cartography in Hungarian academic life (by creating new jobs and publication forums, for example), while, on the other hand, he could integrate Hungarian cartography into international circulation. He strove, in fact, to make Hungary a major force behind the harmonized cartographic work of the socialist block. Parallel to this, Radó became the number one international representative of Hungarian geography: he participated in all the important geographical and cartographical events at a time when, for most geographers, foreign travel was very limited. Thanks to this (and to his former work as an intelligence agent) his name became well known both home and abroad. Radó accumulated numerous awards in Hungary and other socialist countries, especially from their scientific 
Győri, Róbert. "Communist Geography Instead of Nationalist Geography: The New Cadres and the Case of Sándor Radó." Hungarian Cultural Studies. e-Journal of the American Hungarian Educators Association, Volume 8 (2015): http://ahea.pitt.edu DOI: 10.5195/ahea.2015.222

associations, and held important positions in international cartography (Radó admitted in a 1978 interview [published in 1998] that, by that point in his life, he had earned a total of thirty-eight awards; see Habán, Péczi and Saura 1998). Apart from other honors, he was the holder the Order of the Red Banner, the golden rank of the Order of Labor, the Order for a Socialist Homeland, and in the Soviet Union he received the highest military award, the golden rank of the Order of the Great Patriotic War. It is still contested whether or not he actually received the highestranking Soviet medal, the Order of Lenin. When Radó's Soviet superiors sent him on his Moscow trip in 1949, he was hoping to be granted the Order of Lenin (Trom 2006), but, as it soon turned out, Moscow had summoned him to the Soviet Union for completely different reasons. In any case, Radó does not mention this order of merit in his list of medals (Habán, Péczi and Saura 1998), although many who have written about him have claimed that he earned the Order of Lenin in 1942 (see for example K. L. 1960, Ormeling 1982).

Apart from political medals of honor, Radó also received a series of professional acknowledgements both at home and abroad. Among others, he was an honorary fellow of the French Geographical Society, as well as the geographical societies of the GDR, the Soviet Union, and Bulgaria, and was awarded an honorary doctorate by the Lomonosov University in Moscow (in 1977). In the 1960s and 1970s he became the leading international representative of Hungarian geography: he was the president of the Hungarian National Commissions of both the IGU and the International Cartographical Association (ICA) (Kubassek 2010), the head of the ICA's Commission of Thematical Maps from 1972 (Zentai 2010), and from 1973 until his death the president of the Hungarian Geographical Society (Somogyi 1998). The Military Cartographic Services of the GDR (Halle) even took Sándor Radó's name in 1987, becoming the Militärkartogrfischer Dienst (VEB) "Sandor Rado"-Halle/Saale (Nagy M. M. 2010). In Hungary he also received the Kossuth Prize (Kossuth Díj) and the State Prize (Állami Díj) in recognition of his scientific work.

Despite his successes, there were limits to how high he could climb both at home and abroad. In 1967, for example, at the ICA's Amsterdam congress, representatives from the socialist block - probably because of resistance from Western countries - were not able to put through his nomination for vice presidency, which could eventually have led to the presidency (Thomas 1968). Radó also faced failure at home. In 1966 he had to step down from his university chair, because according to a then inaugurated government regulation, high-ranking state officials were prohibited from holding any other positions. Radó came to a crossroads, and he chose the head of division chair at the State Office of Land Survey and Cartography (Állami Földmérési és Térképészeti Hivatal, ÁFTH) over the university (Bora 1998). Then, in the 1970s, he approached György Aczél, the all-powerful lord of Communist science policy, in an attempt to get himself appointed as a fellow of the HAS, but Aczél declined to help him (Kubassek 2010). Different explanations have emerged as to why Radó could not secure this most highly honored Hungarian scientific degree through political channels (after all, this would not have been unprecedented in Hungary, for in the 1950s many party leaders had gained academic fellowships without any scientific achievements at all). Radó himself believed, firstly, that he was "too left-wing" for the Hungarian scientific community (Trom 2006) - which I seriously 
Győri, Róbert. "Communist Geography Instead of Nationalist Geography: The New Cadres and the Case of Sándor Radó." Hungarian Cultural Studies. e-Journal of the American Hungarian Educators Association, Volume 8 (2015): http://ahea.pitt.edu DOI: 10.5195/ahea.2015.222

doubt. Secondly, he suspected that his nomination was blocked by his rival Márton Pécsi (Trom 2010). (As a physical geographer with similarly good party connections, Márton Pécsi was the single geographical fellow of HAS at that time). Others suggest that it is likely that fellows of the Academy did not forget that, on his homecoming in 1955, Radó cast many of them in a negative light, and thus distanced themselves from his nomination (Kisari Balla 2007).

Despite these minor setbacks, Radó was the unquestionable lord of Hungarian geography and cartography in the 1960s and 1970s, a "fixed star" as Béla Sárfalvi, an ELTE department head, proclaimed him (it is worth noting that it was a conflict with Radó that led Sárfalvi to leave the HAS Geographical Research Institute [MTA Földrajztudományi Kutatóintézet] and take up a position at ELTE) (Probáld 2002). On his 80th birthday he was celebrated not only in professional journals (see Anon 1979, Anon 1980), but also in Hungarian newspapers and numerous interviews (for example Szamos 1979). The Földrajzi Közlemények (the scholarly journal of the Hungarian Geographical Society) notably saluted their society's president with a double issue. Nothing could be more telling of his high political standing than a photograph taken on his 80th birthday at a reception held in honor of the Soviet embassy in Budapest (Radó 2006). At this reception, Radó celebrated his birthday in the company of - among others - the Soviet ambassador as well as János Kádár, the secretary-general of the Hungarian Socialist Workers' Party (Magyar Szocialista Munkáspárt, MSzMP). On his death in 1981, the Hungarian press as well as foreign journals also commemorated him with a necrologue (Ormeling 1982). Márton Pécsi (Radó's successor as the Hungarian Geographical Society's president) summarized his lifework in a farewell speech, noting that: "I knew him as someone for whom work, revolutionism, the striving for innovation, Marxist internationalism, and socialist patriotism together formed the essence of his life" [Úgy ismertem meg, mint akinek a munka, a forradalmiság, az újitásra törekvés, a marxista internacionalizmus, a szocialista hazafiság együttesen életeleme volt] (Pécsi 1982: 290).

\section{Being a Communist Geographer: Scientific Ideas and Geographic Thought}

When reassessing the scientific oeuvre of Sándor Radó, we are in many respects put in a difficult position. The first problem is that we cannot know for sure which of his published papers were truly written by himself, and which were created by others, but appeared under Radó's name or joint authorship. There are numerous legends and much gossip on this in the Hungarian professional field, but some of the disciplinary fellows who have remembered Radó in written form have been quite reticent on this matter. Among the many papers dedicated to Radó after 1990, only Ervin Földi's text provides some insight into this problem. As Földi wrote: "Radó was by then [in the second half of the 1970s] not in the position to follow his former practice of making someone write the materials he meant to publish, and then add himself as coauthor" [Radó már nem volt abban a helyzetben, hogy korábbi gyakorlata szerint az általa közzétételre szánt anyagokat megírassa, majd társszerzöként magát feltüntesse] [Földi 1998: 140). Földi mentions several concrete cases: in the first, Radó asked him to provide material for his presentation at a conference, then afterwards, when publishing this work, he considered whether or not to add Földi as coauthor, but finally published Földi's work under his own name 
Győri, Róbert. "Communist Geography Instead of Nationalist Geography: The New Cadres and the Case of Sándor Radó." Hungarian Cultural Studies. e-Journal of the American Hungarian Educators Association, Volume 8 (2015): http://ahea.pitt.edu DOI: 10.5195/ahea.2015.222

(Radó 1970). Two years later, the exact situation emerged, but this time Radó made his subordinate a coauthor (Radó and Földi 1972). Perhaps tellingly, Radó's contribution to the study was, in this case, only a few corrections in style (Földi 1998). Beyond these examples, Földi mentions two more papers, which were written by him, but appeared under Radó's name or coauthorship (Radó 1973, Radó and Földi 1975).

As Földi's case makes clear, it is difficult to estimate exactly how many papers published under Radó's name were truly written by Radó himself (this question can only be resolved by a thorough philological analysis). Nevertheless, Radó's scientific views can be gleaned from these works, for it is more than certain that he agreed on their contents even if he was not the true author of the works in question. However, the second difficulty in reassessing his life's work is the fact that, even if we take everything he "published" into account, Radó's geographical record would still remain rather modest. In his quantitative assessment of Radó's work, Ferenc Probáld remarks sharply that, apart from his cartographical work and organizing activity, "In geography, little value can be given to Radó's activity; if we put aside the works edited - but not writtenby him, then he has practially no scientifically acceptable geographical publications" $[A$ geográfiában igen kevés valódi érték köthetö Radó tevékenységéhez; ha az általa szerkesztett de nem általa írt - müvektöl eltekintünk, jóformán nem is jelent meg tudományos igényü földrajzi publikációja] (Probáld 1999: 233).

Nevertheless, if we try to evaluate the available material and attempt to reconstruct Radó's theoretical views on science, then a portrait of a hard-line, Marxist-Leninist geographer unfolds before us. His relation to the older, "bourgeois" tradition of Hungarian geography (especially Pál Teleki and his disciples) was clearly hostile. As he wrote in 1975: "This backward, obsolete construction of science was destined in its every element to propagate the ideology, the ambitions, and the bourgeois conception of the outdated socioeconomic system, and was devoted to serve its survival" [Ez az elmaradt szemléletü, elavult felépitésü tudomány minden részében az idejétmúlt társadalmi-gazdasági rendszer ideológiáját, törekvéseit, polgári felfogását volt hivatva hirdetni, annak fennmaradását igyekezett szolgálni] (Radó 1975: 101). This condemnation also took on other forms. On one visit to the Department of Cartography at ELTE, for example, he had Teleki's portrait removed from the wall (Kubassek 2010). And, in 1979, at a general meeting of the Hungarian Geographical Society, he dismissed a proposal to reevaluate Teleki's work at a conference to be organized on the occasion of the 100th anniversary of Teleki's birth with the following words: "Please, everything has already been written about Teleki by the Népszabadság [the newspaper of the Central Committee of the Hungarian Socialist Workers' Party (MSzMP), which at the time had the largest readership of all Hungarian newspapers], so speak no more about Teleki" [Telekiröl kérem már mindent megírt a Népszabadság, úgyhogy Telekiröl többé ne essen szó] (Probáld, 1999: 233).

The central issue that dominated his publications appearing in the second half of the 1950s and the early 1960s was the introduction of Soviet geography (particularly economic geography) to Hungarian science (Radó 1957a, Radó 1957b). In these papers, Radó evaluated the evolution of Russian geography in a presentist way through the perspective of Marxist-Leninist geography, emphasizing in the usual fashion the "intuitive materialism" of nineteenth-century 
Györi, Róbert. "Communist Geography Instead of Nationalist Geography: The New Cadres and the Case of Sándor Radó." Hungarian Cultural Studies. e-Journal of the American Hungarian Educators Association, Volume 8 (2015): http://ahea.pitt.edu DOI: 10.5195/ahea.2015.222

progressivist Russian geographers, and the "revolutionism" of a generation of scholars in the 1910s and 1920s (Radó 1957b). Soviet geography’s developmental path was discussed in the context of Lenin's thoughts and the Soviet Communist Party's economic and developmental policy. Of the most debated theoretical question (the question of the unity of geography) he explained faithfully the Soviet view that the idea of geography as a unified discipline was in contradiction with the foundations of Marxism. Physical geography and human geography, he argued, are two different disciplines: the former belongs to the natural sciences, the latter to the social sciences. In the 1930 s, one of the most important tasks of Soviet geography was "to continue the ideological battle against bourgeois theories," as well as against environmental determinism, and "especially against Hettner's tenets and the bourgeois descriptive geography, and furthermore [...] against Weber's location theory" [ideológiai harcot folytasson a burzsoá teóriák ellen, 'a földrajzi determinizmus, 'föképpen Hettner tanai és a burzsoá leíró földrajz ellen, továbbá Weber standort-teóriája [...] ellen] (Radó 1957a: 491). Environmental determinism was an unacceptable view according to the Marxist-Leninist perspective, because social phenomena and economic disparities became interconnected with natural factors, instead of explaining them with the forces of production and the modes of production. Radó, however, emphasized that the aim of the newest Soviet ambitions was to draw the two geographical sciences closer together (Radó 1957b).

On the other pivotal issue of debate in Marxist-Leninist geography, namely the relationship between theoretical and applied research, Radó again followed the official Soviet view, arguing for the prominent role of applied research. As he argued, "[...] in the Soviet Union, geography is one of the most important components of the scientific base of theory, on which Soviet people can lean to actively transform their country's natural environment. Following the inspiring example of Soviet geographers, Hungarian geographers must [...] also be aware that, instead of abstract studies, they have to adjust first and foremost to the needs of the Socialist people's economy and culture" [(...) a Szovjetunióban a földrajz a tudományos elméleti bázis egyik legfontosabb része, amelyre támaszkodva a szovjet emberek országuk természeti viszonyait aktivan megváltoztatják. A szovjet geográfusok lelkesítö példáját követve a magyar geográfusoknak is (...) ügyelniük kell arra, hogy elvont jellegü munkák helyett elsősorban a szocialista népgazdaság és a kultúra igényeihez igazodjanak] (Radó 1957b: 318). The will to conform to the needs of a Socialist people's economy and culture demanded from geography an active contribution to building Communism. Radó derived this task from the resolutions of the 22nd Congress of the Soviet Communist Party and from the ideas of Khrushchev. The main goal of the programme conceived at the 22nd Congress was to strengthen the material and technological foundations of the Communist society, a goal that gave science a leading role (Radó 1962).

Through the implementation of this program, two great tasks were assigned to geography. Of the first task Radó wrote: "The building of Communism calls forth the ever considerable transformation of nature in human life [...] which is why the chief concern of physical geography is regional geography, the examination of the landscape as the immediate theater of human social and economic activity" [A kommunizmus építése az emberiség életében a természetnek mind 
jelentösebb átalakitását vonja maga után, [ ...] ezért a természeti földrajz fö feladata a tájkutatás, a tájnak mint az emberi társadalom gazdasági tevékenysége közvetlen színterének tanulmányozása]. Of the second task, Radó argued that "the analysis of the regional distribution of industry [...] is the foremost important problem of economic geography both in the Soviet Union and in our country" [Az ipar területi elhelyezkedésének vizsgálata [...] a gazdasági földrajznak egyik legfontosabb problémája mind a Szovjetunióban mind nálunk] (Radó 1962: 229). Compared to the "old" Hungarian geography, these new approaches to research meant an entirely different role for geography, one in which economic geography would be embedded within the broader planning of the people's economy. The importance of the latter was accentuated by Radó when he wrote that "The time is ripe in domestic relations to shift [our focus] towards the assertion of the principle of spatial planning" [Hazai viszonylatban is megérett az idö arra, hogy áttérjünk a területi tervezés elvének érvényesitésére] (Radó 1962: 230).

Despite his authoritative pronouncements, the truth is that Radó's contribution to the Hungarian adaptation of Soviet geography was preempted and thus diminished by the fact that the uncritical acceptance of the principles of Marxist-Leninist geography, and its solidification as a binding dogma of scholarly production, had already occurred in Hungary in the early 1950s, primarily due to the work of György Markos and his disciples (Gyuris and Györi 2013). Thus, Radó's thoughts in the late 1950s and the early 1960s can be counted neither as something new, nor as genuine scientific innovations in Hungarian science.

At the same time, however, Radó's publishing activity during this period was rather wide-ranging, because apart from his theoretical studies (for example Radó 1960) and minor cartographical writings, he also published papers on Humboldt's life and geographical work (Radó 1959b), on geomorphological problems (Radó 1958), and also on political geographical matters (Radó 1959a). Much more important from these was the organizing and lobbying he did in the field of geography and cartography. Since Radó played a leading role in two scientific institutions (the ÁFTH and the MKKE Department of Economic Geography), he had the opportunity to place his subordinates into large-scale projects. In order to carry out and to finance his projects, he also mobilized his political connections (Papp-Váry 2010).

In 1957, for instance, Radó organized a team of seven or eight faculty members from the MKKE and the ÁFTH whose task was to produce the International Almanac (Nemzetközi Almanach). The first edition of this massive handbook ${ }^{3}$ showing the world's countries with detailed data was published in 1959, and Radó's plans were to update it yearly, but — despite its success - they only managed to do this three times (Radó ed. 1959), though it was also published in German in 1962 (Radó ed. 1962). The data for these volumes were collected by Radó from national and international statistical yearbooks with the help of widespread correspondence.

\footnotetext{
${ }^{3}$ The first edition ran to 900 pages. The last edition was 1500 pages in length.
} 
Győri, Róbert. "Communist Geography Instead of Nationalist Geography: The New Cadres and the Case of Sándor Radó." Hungarian Cultural Studies. e-Journal of the American Hungarian Educators Association, Volume 8 (2015): http://ahea.pitt.edu DOI: 10.5195/ahea.2015.222

Radó's further contribution to this project consisted of editorial work and the expansion of the almanac's readership. These handbooks were published in many thousands of copies, and what contributed greatly to their success was that, at the time, access to basic geographical and economical information in Hungary was very restricted. Apart from this, "market success" was guaranteed because of state support. The MSzMP, for example, "distributed several thousand copies of the 1960 edition to its party workers" [az 1960-as kiadásból az MSzMP saját pártmunkásainak több ezer példányt szétosztott] (Bora 2010: 192). Another contribution that Radó made with respect to his university activity was his textbook editorship. Already in the early 1950s, the MKKE Department of Economic Geography became the "truth spot" of Hungarian Marxist-Leninist economic geography, where leading studies and textbooks were produced. Radó's effort in the production of these textbooks was confined to tasks in editing and proofreading, and he did not participate in writing chapters (Radó ed. 1963, Radó ed. 1967).

Not long after his homecoming in 1955, Radó started another enterprise, the forerunners of which were the mapmaking press agencies that had functioned between the two world wars. In 1957, under the framework of ÁFTH, the Terra Térképszolgálat ['Terra Map Service'] was established, which provided maps to journals in order to illustrate topical (mostly political) events. The demand for this service grew rapidly, and in the 1960s they even started producing maps for foreign orders. After its golden era in the 1970s, however, the company collapsed in 1988 on the eve of the regime change due to diminishing customers and other economic difficulties (Csáti and Saura 1998).

Much more significant than these projects (and having a positive effect on the whole of Hungarian cartography) was Radó's role in international cartography. The development of his career in international cartography began as the result of a Soviet initiative. Although the IGU had already decided in the nineteenth century that it would support the creation of a unified map of the whole of the Earth's surface, the actual work towards this end had made very little progress even in the first half of the twentieth century. In 1954 the UN Office of Cartography took over the coordination of this work, and sought to accelerate the publishing of map sheets. But the scale used in these maps (1:1 000 000) was classified in the Soviet Union, so Soviet specialists proposed the production of a smaller scale (1:2500 000) world map. Because the UN rejected the Soviet proposal, Radó therefore suggested at a meeting of the geodesy service of socialist countries in Prague that this world map should be created by socialist countries (PappVáry 1998a).

From this point forward, Radó was able to ensure his own (and Hungary's) leading role in the grand project. After many preparatory committee sessions, the council in Moscow ordered that an editorial board be established, with Radó serving as its president until the termination of the project. This same council also decided to create two information offices, which thus made Budapest Moscow's partner as a centre for the project (the task of the Budapest office was to gather information on mainlands) (Papp-Váry 1998a). Thanks to Radó's lobbying activity, Budapest became one of the cartographical centres of socialist countries (at least for a few decades). To serve in the production of this world map, the Budapest office collected large numbers of recently produced foreign maps, as well as databases and other materials; in fact, 
Győri, Róbert. "Communist Geography Instead of Nationalist Geography: The New Cadres and the Case of Sándor Radó." Hungarian Cultural Studies. e-Journal of the American Hungarian Educators Association, Volume 8 (2015): http://ahea.pitt.edu DOI: 10.5195/ahea.2015.222

from the early 1960s Budapest held thematic international map exhibitions and conferences on a yearly basis, all the materials of which enriched the database (Rátóti 1998). Perhaps not surprisingly, this large-scale cartographical and statistical data collecting attracted the abovementioned interest of the CIA (Thomas 1968).

The growth of this ever-growing and increasingly vast archive of material laid the foundation for Radó's most successful international enterprise. Since fresh maps and data were arriving in Budapest from all corners of the world, Radó and his colleagues developed the idea of an international journal, one that would present in multiple languages and in map form the political, economic, and infrastructural changes (new borders, administrative boundaries, railway lines, roads, and so on) that were occurring in all parts of the world (Csáti 1998). The new journal, which was given the title Cartactual, was launched in 1965 with Radó as editor in chief and the employees of Kartográfiai Vállalat as its editors. Each issue was twelve to fourteen pages in length, and appeared with English, German, French, and Hungarian legends, at first quarterly, but afterwards every two months. In 1971 the journal was extended with the addition of a Cartinform inset, which presented the latest cartographical publications (it actually consisted of editors' advertisements). Up to the early 1980s, the journal had roughly 600 exclusively international subscribers, and it is perhaps not an exaggeration to suggest that, in its own field, it became an international standard. In the second half of the 1980s, however, conditions for publishing the journal continuously deteriorated, firstly because the economic crisis in socialist countries reduced the number of subscribers, and secondly because this crisis also increased the costs of production. Thus the journal was first forced to reduce regular publication, then in 1993 it ceased its operation entirely (Gercsák, Habán, and Tóth 1998).

\section{Afterlife: Radó's Reception after 1990}

Although Sándor Radó held the most important positions in Hungarian geography in the 1960s and 1970s, his scholarly prestige at home never matched whatever influence he may have had more generally. Radó did not develop a school of thought, for example, nor did he have an explicit scientific profile, or any disciples (even his cartographer colleagues were more his subordinates than his companions within the profession). In all likelihood this was one of the reasons why, after his death, Radó's name quickly faded, not least of which within Hungarian geographical circles. The other obvious reason was the reticence of Hungarian geographers to confront the socialist past after the regime change in 1990. Though the nature and methods of economic geography remained largely unaltered (only the covers of textbooks and the names of departments changed) (Timár 2006), the "incriminating" names and references of the Soviet-era were deleted from the texts. This largely cosmetic "cleansing" - a process that helped preserve the careers of some socialist-era scholars, and even helped perpetuate Marxist-Leninist interpretations and approaches after 1990 - gave rise to a general silence with respect to the socialist past of geography as a discipline, and with this also many geographers whose work was never evaluated, and whose names remained "unspoken." It was within this context that Radó, whose Marxist-Leninist convictions were beyond doubt, fell into oblivion (I myself studied geography at the university of Budapest in the middle of the 1990s, and as a student I never 
Győri, Róbert. "Communist Geography Instead of Nationalist Geography: The New Cadres and the Case of Sándor Radó." Hungarian Cultural Studies. e-Journal of the American Hungarian Educators Association, Volume 8 (2015): http://ahea.pitt.edu DOI: 10.5195/ahea.2015.222

heard Radó's name, nor were any of his papers or books included in our reading lists or in the references of our textbooks. It was only later, as a young professor and thus "insider," that I first heard about the legends and gossip surrounding him).

Given his descent into obscurity after 1990, it is perhaps understandable why his partial "resurrection" in 1998 was met with some surprise and even revulsion when Hungary's leading geographical journal, Földrajzi Közlemények, decided to dedicate a double issue to Radó’s memory in honor of the 100th anniversary of his birth. For the most part it was his former colleagues who wrote in this double issue. Writing in a predominantly commemorative tone, the studies generally refrained from a profound reassessment of Radó's ouevre. Most of the authors praised Radó's merits, with very few papers aiming to articulate a more nuanced picture. There were, however, one or two papers that did offer a critique of Radó by addressing some of the legends that surrounded him. In the following issue of Földrajzi Közlemények, Ferenc Probáld, a member of the journal's editorial board and also a professor at ELTE, published an open letter criticizing the editor-in-chief for publishing a double issue commemorating Radó without even asking the editorial board (Probáld 1999). In the beginning of his letter, Probáld noted that it was unprecedented in the history of Földrajzi Közlemények to have a double issue dedicated to anyone. He emphasized, moreover, that Radó's geographical work (apart from his cartographical output) was of little scholarly import, and that the double issue was therefore of questionable value. He objected as well that the manuscripts appearing in the memorial issue were not subjected to the usual proofreading and review process.

The journal's then editor-in-chief, Antal Nemerkényi, wrote in his reply that he was only fulfilling the request of his cartographer colleagues when he agreed on the publication of the manuscripts prepared and edited by them in Földrajzi Közlemények (Nemerkényi 1999). He also justified his bypassing of the editorial board by explaining that Földrajzi Közlemények was suffering from financial problems, and that the double issue was financed entirely by Kartográfiai Vállalat. Furthermore, he felt it important to publish these recollections, given that they were primarily of a documentative nature. The lack of the usual review process was also due to this. Nemerkényi recognized that the commemorative recollections had subjective elements embedded within them, and therefore felt it necessary to leave the peer-reviewing task to the readers of the journal. Given the different perspectives and portraits sketched out in the double issue, the readership of Földrajzi Közlemények, he insisted, were capable of drawing their own conclusions about Radó.

Though it broke the silence around Radó, the Földrajzi Közlemények double issue did not elicit an intensive debate on Radó's oeuvre. Similary, an extended edition of Dóra jelenti published in 2006 by Radó's stepson, András Trom, received little attention in professional academic circles (Radó 2006). In 2009, however, a conference which dealt with Radó's geographical-cartographical work and also his career as an intelligence agent was organized on Trom's initiative by the Museum of Military History (Hadtörténeti Múzeum). It was in conjunction with this conference that the museum erected a memorial plaque in its courtyard. The proceedings of the conference were later published in a separate volume (Hegedüs and Suba 
Győri, Róbert. "Communist Geography Instead of Nationalist Geography: The New Cadres and the Case of Sándor Radó." Hungarian Cultural Studies. e-Journal of the American Hungarian Educators Association, Volume 8 (2015): http://ahea.pitt.edu DOI: 10.5195/ahea.2015.222

2010). Listing foreign authors alongside Hungarian scholars, the majority of the studies were critical assessments rather than celebratory commemorations of Radó's life and work.

\section{Conclusion}

In summarizing Sándor Radó’s communist-era activities in Hungary, we must first state that his scientific performance was not at all in line with the prestigious positions he held in scientific life. Having attained his scholarly position through political support, his career was far from unique: after the Soviet-style transformation of Hungarian science in the 1950s, every scientific field had its own omnipotent "ceasar," a dominant figure who gained control over an entire discipline not because of their professional achievements, but because of their political background and reliability. The control that Radó exercised over Hungarian science was typical of the arbitrary and authoritative nature of Hungarian scholarship after 1949. Like his counterparts in other fields, Radó had almost complete control over his subordinates. He determined not only how many hours they worked and when, but also dictated their research activity, and indeed the course of their careers. He often claimed co-authorship of studies he played no part in, and tied the financing of projects and international collaboration to political considerations. No doubt this practice was not confined to Hungary, but was present to some degree in the scientific environments of all socialist countries.

When reviewing the Hungarian reception of Radó, it is clear that his advocates and his opponents alike, both past and present, acknowledge his organizing and lobbying skills, and recognize that, on some level at least, Hungarian geography and, above all, Hungarian cartography benefited from his efforts. However - in my opinion-these successes could only emerge from the particular scientific environment of socialism. The information necessary for publishing Carcatual, for example, made its way into Hungary through the framework of a "socialist division of labor," and the development of this division of labor is attributable to Radó's political rather than his professional merit. Without political support, Radó could not occupy the positions he did in order to secure the "workers" as well as the financial support (and eventually even the market) for his endeavors. Apart from this, an important contributing factor behind the international success of Carcatual was that the high quality professional work in Hungary was performed by specialists who earned rather dismal wages when compared to their counterparts in the West. It is not a coincidence, therefore, that Terra Térképszolgálat and Carcatual did not survive much after Radó and the collapse of the socialist system.

Within the context of the contemporary reception of Radó in Hungary, it is conspicuous that there is no consensus on the value of his professional, political, or even espionage activities. Opinions with regard to Radó oscillate on an extreme scale, with both his admirers and critics using adjectives that approach the superlative. Sándor Somogyi, for example, who was the secretary-general of the Geographical Society under Radó's presidency, wrote that: "on the 100th anniversary of his birth, we commemorate with widening honor and great esteem Sándor Radó, who [was] [...] an outstanding practitioner of Hungarian and general geography" [Születésének 100. évfordulóján egyre szélesedö tisztelettel és nagyrabecsüléssel gondolunk vissza Radó Sándorra, aki (...) kiemelkedö müvelöje (volt) a magyar és egyetemes 
földrajztudománynak] (Somogyi 1998: 125). Lt. Gen. József Holló, in turn, the director of the Museum of Military History, wrote in the preface of the volume on Radó that: "With this conference volume, let us commemorate and bow our heads to Sándor Radó, the famous geographer and cartographer, or as many know him, 'Dóra', the renowned intelligence agent, and above all the PERSON, or the saviour of people, whose life and professional career could be exemplary to many" [Ezzel a konferenciakötettel hajtsunk fejet és emlékezzünk Radó Sándorra, a híres földrajztudósra és térképészre, vagy ahogyan sokan ismerik, „Dórára”, a neves hírszerzöre, és mindenekelött az EMBERRE, az embermentöre, akinek élete, szakmai munkássága sokak számára példa lehet] (Holló 2010: 8). By contrast, Radó’s former subordinate, György Kisari Balla, has described Radó as a "malicious genius" [rosszindulatú zseni] (Kisari Balla 2007), while the academic István Klinghammer, though he recognizes Radó's merits, does not forget the darker side of his personality, writing that in "his personal relationships" Radó was an "infinite egoist"who acted like a "learned banker" [az emberi kapcsolatiban a végtelenségig egoista, müvelt bankember habitusú] (Klinghammer 2010: 11). A similarly divided opinion exists with respect to both his political activity, and his past as a spy, suggesting that the current assessment of his life and work cannot be understood outside the political context within which it is offered.

Translated by Zoltán Gyimesi and Steven Jobbitt

\section{Works Cited}

Anon. 1979. "Radó Sándor 80 éves" ['Sándor Radó is 80 Years Old']. Geodézia és kartográfia ['Geodesy and Cartography'] 32: 372.

Anon. 1980. "Tisztelettel és szeretettel köszöntjük Radó Sándor Kossuth- és Állami-díjas egyetemi tanárt, társaságunk elnökét 80. születésnapja alkalmából!' ['Warm Wishes for Sándor Radó, Kossuth- and State-Prize Winning University Professor and Our Society's Director, on the Occassion of His 80th Birthday']. Földrajzi Közlemények ['Geographical Review'] 104: 3-4.

ÁBTL A-748 "Feljegyzés a 'Vörös zenekar' nevü Svájcban müködő hírszerző rezidentúráról" [The Report of Agent 'Red Orchestra' Working in Switzerland]. Állambiztonsági Szolgálatok Történeti Levéltára ['Historical Archives of the Hungarian State Security'] ÁBTL O-16896 "Kartográfiai Vállalat” ['Kartográfia Company']. Állambiztonsági Szolgálatok Történeti Levéltára ['Historical Archives of the Hungarian State Security']

Bora, Gyula. 1998. "Radó Sándor a Budapesti Közgazdaságtudományi Egyetem oktatója" ['Sándor Radó-A Lecturer at the Budapest University of Economic Sciences']. Földrajzi Közlemények ['Geographical Review'] 122: 109-116. 
——. 2010. "Radó Sándor, a Nemzetközi Almanach szerkesztője” ['Sándor Radó, the Editor of International Almanach']. In Tanulmányok Radó Sándorról ['Essays on Sándor Radó']. Ed. Ábel Hegedüs and János Suba. Budapest: HM Hadtörténeti Intézet és Múzeum: 191-194.

Csáti, Ernő. 1998. "A Cartactual születéséröl”' ['On the Birth of Cartactual']. Földrajzi Közlemények ['Geographical Review'] 122: 203-204.

Csáti, Ernő and Róbert Saura. 1998. "A Terra Térképszolgálat" ['The Terra Map Service’]. Földrajzi Közlemények ['Geographical Review'] 122: 199-200.

Földi, Ervin. 1998. “Az ENSZ földrajzinév-egyesítési törekvései, a Magyar Földrajzinévbizottság megalakulása és tevékenysége 1978-ig” ['UN Efforts for Standardizing Geographical Names, the Setting Up and the Activities of the Hungarian Committee of Geographical Names to 1978']. Földrajzi Közlemények ['Geographical Review'] 122: 131-144.

Gercsák, Gábor, Ildikó Habán and Mária Tóth. 1998. "A Cartactual és a Cartinform” ['On Cartactual and Cartinform']. Földrajzi Közlemények ['Geographical Review'] 122: 173182.

Gyimesi, Zoltán. 2014. "The Contested Post-Socialist Rehabilitation of the Past: Dual Narratives in the Republishing of Tibor Mendöl's Introduction to Geography." Hungarian Cultural Studies 7: 242-273.

Győri, Róbert. 2009. “Tibor Mendöl.” In Geographers: Biobibliographical Studies 28. Ed. Charles W. J. Withers and Hayden Lorimer. London: Continuum: 39-54.

Györi, Róbert and Ferenc Gyuris. 2012. "The Sovietisation of Hungarian Geography, 19451960." Mitteilungen der Österreichischen Geographischen Gesellschaft ['Review of the Austrian Geographical Society'] 154: 107-128. . 2013. "Sovietised Science at the Service of 'Socialist National Economy': The Example of Hungarian Geography, 1945-1960." Berichte: Geographie und Landeskunde ['Review: Geography and Regional Studies'] 87.1: 7-25.

- 2015. "Knowledge and Power in Sovietized Hungarian Geography." In Geographies of Knowledge and Power (Knowledge and Space; 7). Ed. Peter Meusburger, Derek Gregory and Laura Suarsana. Dordrecht: Springer: 203-233.

Habán, Ildikó, Ernő Péczi and Róbert Saura. 1998. "Riport dr. Radó Sándorral” ['Report with Sándor Radó']. Földrajzi Közlemények ['Geographical Review'] 122: 217-228.

Hajdú, Zoltán. 1990-91. "A Tanyai Tanács története" ['The History of the Scattered Farm Council']. Alföldi Tanulmányok ['Alföld Studies'] 14: 105-124. . 1992. "Település- és településhálózat-fejlesztési politika Magyarországon az államszocializmus időszakában" ['Settlement Network and Urban Development Policy in Hungary during the Communism']. Földrajzi Közlemények ['Geographical Review'] 116.1-2: 29-37.

Heffernan, Michael. 2015. "The Interrogation of Sándor Radó: Geography, Communism and Espionage in World War Two.” Journal of Historical Geography 47: 74-88. 
Heffernan, Michael and Róbert Győri. 2014. "Sándor Radó.” In Geographers:

Biobibliographical Studies 33. Ed. Charles W. J. Withers and Hayden Lorimer. London:

Bloomsbury: 167-202.

Hegedüs, Ábel and János Suba, eds. 2010. Tanulmányok Radó Sándorról ['Essays on Sándor Radó']. Budapest: HM Hadtörténeti Intézet és Múzeum.

Hegyi, Gyula. 1998. "Radó Sándor szerepe a Kartográfiai Vállalat életében” ['Sándor Radó’s Role in the Life of Cartographia']. Földrajzi Közlemények ['Geographical Review'] 122: $117-124$.

Izsa, Jenő. 2010. "Radó Sándor, a hírszerző” [‘Sándor Radó, the Intelligence Officer']. In Tanulmányok Radó Sándorról ['Essays on Sándor Radó']. Ed. Ábel Hegedüs and János Suba. Budapest: HM Hadtörténeti Intézet és Múzeum: 95-116.

Jobbitt, Steven. 2014. "Scholarly Production in Desperate Times: Ferenc Fodor and the Question of Academic Relevancy in Communist Hungary, 1948-1962." In Földrajz-és földtudomány az Eötvös Collegiumban. ['Geography and Earth Sciences at the Eötvös Collegium'] Ed. Róbert Győri. Budapest: Eötvös Collegium: 195-213.

K. L. 1960. "Radó Sándor, a Magyar Földrajzi Társaság Társelnöke 60 éves” ['Sándor Radó, the Co-President of the Hungarian Geographical Society is 60 Years Old']. Földrajzi Közlemények ['Geographical Review'] 84: 220-223.

Kisari Balla, György. 1999. "Dóra jelenti-és amit nem jelentett" ['Dora Reports—and What $\mathrm{He}$ Did Not Report']. Manuscript, Budapest: MTA Kézirattár.

—. 2007. "Dóra jelenti—és amit (fogadott fia) sem jelentett." ['Dora Reports—and What Even His Stepson Did Not Report']. Manuscript, Budapest: MTA Kézirattár.

Klinghammer, István. 2010. "Radó Sándor (1899-1981)", In Tanulmányok Radó Sándorról ['Essays on Sándor Radó']. Ed. Ábel Hegedüs and János Suba. Budapest: HM Hadtörténeti Intézet és Múzeum: 9-11.

Koch, Ferenc. 1952. "A Magyar Földrajzi Társaság újjáalakulása" ['Reestablishment of the Hungarian Geographical Society']. Földrajzi Értesitő ['Geographical Bulletin'] 1: 884887.

Kubassek, János. 2010. “Mit köszönhet a földrajztudomány Radó Sándornak?” ['What Can Geography Thank Sándor Radó For?']. In Tanulmányok Radó Sándorról ['Essays on Sándor Radó']. Ed. Ábel Hegedüs and János Suba. Budapest: HM Hadtörténeti Intézet és Múzeum: 147-165.

Livingstone, David. N. 1992. The Geographical Tradition. Episodes in the History of a Contested Enterprise. Chicago: Chicago University Press.

Nagy, Edit Ágnes. 2010. “A szocialista propaganda embereszménye: Radó Sándor” ['The Ideal Man of Socialist Propaganda: Sándor Radó']. In Tanulmányok Radó Sándorról ['Essays on Sándor Radó']. Ed. Ábel Hegedüs and János Suba. Budapest: HM Hadtörténeti Intézet és Múzeum: 261-267. 
Győri, Róbert. "Communist Geography Instead of Nationalist Geography: The New Cadres and the Case of Sándor Radó." Hungarian Cultural Studies. e-Journal of the American Hungarian Educators Association, Volume 8 (2015): http://ahea.pitt.edu DOI: 10.5195/ahea.2015.222

Nagy, Miklós Mihály. 2010. "Radó Sándor szerepe a magyar hadiutazások történetében" ['Sándor Radó's Role in the History of Hungarian Military Missions']. In Tanulmányok Radó Sándorról ['Essays on Sándor Radó']. Ed. Ábel Hegedüs and János Suba. Budapest: HM Hadtörténeti Intézet és Múzeum: 225-245.

Ormeling, Ferdinand Jan. 1982. "Az ICA megemlékezik Radó Sándor professzorról” [‘The ICA Commemorates Professor Sándor Radó']. Geodézia és Kartográfia ['Geodesy and Cartography'] 34: 298-299.

Papp-Váry, Árpád. 1998a. "Iskolai atlaszok kiadása az 1950-es években" ['The Publication of School Atlases in the 1950s']. Földrajzi Közlemények ['Geographical Review'] 122: 201202. . 1998b. “Az 1:2 500000 méretarányú nemzetközi világtérkép” ['The 1:2 500 000-scale international world map'] Földrajzi Közlemények ['Geographical Review'] 122: 145-166. . 2010. "Radó Sándor, a Mezőgazdasági és Élelmezésügyi Minisztérium főosztályvezetője" [Sándor Radó, Head of Divison at the Ministry of Agriculture and Food']. In Tanulmányok Radó Sándorról ['Essays on Sándor Radó']. Ed. Ábel Hegedüs and János Suba. Budapest: HM Hadtörténeti Intézet és Múzeum: 166-180.

Pécsi, Márton. 1982. "Búcsúbeszéd Radó Sándor (1899-1981) ravatalánál" ['Eulogy for Sándor Radó (1899-1981)]. Földrajzi Közlemények ['Geographical Review'] 106: 290-292.

Péteri, György. 1998. Academia and State Socialism. New York: Columbia University Press. Poltorak, Szergej Nyikolajevics. 2010. "Két Radó: két sors” ['Two Radós, Two Fates']. In Tanulmányok Radó Sándorról ['Essays on Sándor Radó']. Ed. Ábel Hegedüs and János Suba. Budapest: HM Hadtörténeti Intézet és Múzeum: 117-128.

Probáld, Ferenc. 1999. "Radó Sándor és a magyar földrajztudomány-különvélemény” ['Sándor Radó and the Hungarian geography—A Dissenting Opinion']. Földrajzi Közlemények ['Geographical Review'] 123: 233-234.

. 2002. "A Regionális Földrajz Tanszék 50 éve" [“Fifty years of the Department of Regional Geography at ELTE']. In: A Regionális Földrajzi Tanszék jubileuma ['The Department of Regional Geography Jubilee']. Regionális Tudományi Tanulmányok 7. ['Papers on Regional Science 7'] Ed. Nemes Nagy József Budapest: ELTE Regionális Földrajzi Taszék: 9-25.

Radó, Sándor. 1938. The Atlas of To-Day and To-Morrow. London: Victor Gollancz.

—. 1957a. "Adatok a szovjet gazdaságföldrajz történetéhez" ['Some Data on the History of Soviet Economic Geography']. Földrajzi Értesitö ['Geographical Bulletin'] 6: 490-492. . 1957b. "A szovjet földrajztudomány 40 éve" ['Fourty Years of Soviet Geography']. Földrajzi Közlemények ['Geographical Review'] 81: 305-318. - 1958. "A francia geográfusok a geomorfológiai formák osztályozásáról” ['French Geographers on the Classification of Geomorphological Forms']. Földrajzi Értesitö ['Geographical Bulletin'] 7: 242-245. . 1959a. "Az imperializmus és a szocializmus politikai földrajzi vázlata" ['An Outline of Imperialist and Socialist Political Geography']. Földrajzi Közlemények ['Geographical Review'] 83: 197-233. 
.1959b. "Humboldt a geográfus" ['Humboldt the Geographer']. Földrajzi Közlemények ['Geographical Review'] 83, 321-341.

ed. 1959. Nemzetközi Alamanch. ['International Almanach'] Budapest: Kossuth Kiadó. 1960. "Lenin és a földrajztudomány" ['Lenin and Geography']. Földrajzi Közlemények ['Geographical Review'] 84: 225-250.

— 1962. "A kommunizmus építése és a földrajzi tudományok" ['The Construction of Communism and Geographical Sciences']. Földrajzi Közlemények ['Geographical Review'] 86: 225-232.

—. ed. 1962. Welthandbuch, internationaler, politischer und wirtschaftlicher Almanach ['World Handbook, International Almanach on Polictics and Economics']. Budapest: Corvina.

ed. 1963. Magyarország gazdaságföldrajza ['Economic Geography of Hungary']. Budapest: Gondolat Kiadó. . ed. 1967. A világgazdaság földrajza. ['Geography of World Economy’]. Budapest: Gondolat Kiadó.

. 1970. "Névtudomány és kartográfia" ['Geographical Naming and Cartography']. Geodézia és kartográfia ['Geodesy and Cartography']. 22: 15-17. 1971. Dóra jelenti. ['Codename Dora'] Budapest: Kossuth Könyvkiadó. . 1973. "ENSZ szakértői ülés a földrajzi nevek szabványosításáról New Yorkban" ['Session of UN Group of Experts on the Standardization of Geographical Names in New York']. Geodézia és kartográfia ['Geodesy and Cartography'] 25: 294-295. . 1975. "Harminc év a magyar földrajztudományban" ['Firty Years of Hungarian Geography']. Földrajzi Közlemények ['Geographical Review'] 99: 101-108. 1977. Codename Dora. The Memoirs of a Russian Spy. London: Abelard . 2006. Dóra jelenti (Ötödik, bővitett, javitott és átszerkesztett kiadás) ['Codename Dora (Fifth extended, corrected and revised edition)']. Budapest: Kossuth Kiadó.

Radó, Sándor and Földi Ervin. 1972. "Map Lettering - an Important Element of Cartographic Communication.” In: Hungarian Cartographical Studies. Budapest: Institute of Surveying: 47-49. . 1975. "Az ENSZ földrajzinév-szakértői csoportjának hatodik ülésszaka” ['Sixth Session of the UN Group of Experts on Geographical Names']. Geodézia és kartográfia ['Geodesy and Cartography'] 28: 68-70.

Rátóti Benő. 1998. "Radó Sándor, a sikeres konferenciák és kiállítások elindítója” ['Sándor Radó, Promoter of Successful Conferences and Exhibitions']. Földrajzi Közlemények Geographical Review'] 122: 193-198.

Romsics, Ignác. 2011. "Szovjetizált múltkutatás. A magyar történetírás gleichschaltolása, 19451949" ['Sovietized Historical Research: The Appropriation of Hungarian Historiography, 1945-1949']. Rubicon 22. 5: 68-82.

Somogyi, Sándor. 1998. "Radó Sándor szerepe a Magyar Földrajzi Társaság életében” [‘Sándor Radó's Role in the Life of the Hungarian Geographical Society']. Földrajzi Közlemények ['Geographical Review'] 122: 125-130. 
Szamos, Gábor. 1979. "Beszélgetés dr. Radó Sándorral” ['Interview with dr. Sándor Radó']. Geodézia és kartográfia ['Geodesy and Cartography'] 32: 343-347.

Timár, Judit. 2006. "The Transformation of Social and Cultural Geography During the Transition Period (1989 to present time) in Hungary. A társadalom- és kulturális földrajz átalakulása Magyarországon az átmenet korszakában (1989-től napjainkig).” Social \& Cultural Geography 7/4: 649-667.

Thomas, Louis. 1968. “Alexender Rado.” Studies in Intelligence, 12: 41-61.

Trom, András. 2006. "A teljes Dóra jelenti margójára" ['To the Margin of the whole Codename Dora']. In Dóra jelenti (Ötödik, bövitett, javitott és átszerkesztett kiadás) ['Codename Dora (Fifth extended, corrected and revised edition)']. Budapest: Kossuth Kiadó: 5-15.

_ 2010. "Radó Sándor sorstörténete és munkásságának jelentősége" ['The Significance of Sándor Radó's Life and Work']. In Tanulmányok Radó Sándorról ['Essays on Sándor Radó']. Ed. Ábel Hegedüs and János Suba. Budapest: HM Hadtörténeti Intézet és Múzeum: 12-29.

Zentai, László. 2010. "Radó Sándor szerepe nemzetközi szervezetekben” ['Sándor Radó's Role in International Organisations']. In Tanulmányok Radó Sándorról ['Essays on Sándor Radó']. Ed. Ábel Hegedüs and János Suba. Budapest: HM Hadtörténeti Intézet és Múzeum: 181-186. 